\title{
SOLVENCY TEST AS YARDSTICK FOR PRUDENT DIVIDEND DISTRIBUTION: A CROATIAN OUTLOOK
}

\author{
Kristijan Poljanec * \\ Hana Horak **
}

\begin{abstract}
Building their paper around long-standing critics of the EU capital maintenance regime and the distribution rules thereof, the authors consider introducing additional instruments for creditor protection into Croatian company law, where special regard is paid to the 'solvency test'. Given the scope and aim of the EU Codification Directive, the paper seeks to find out whether and to what extent such a test could be introduced into Croatian law. The paper argues that the EU regime allows the introduction of the solvency test into Croatian law on public limited companies as a distribution test complementary to the two-fold 'balance sheet test' leaving, however, entirely to the Croatian legislator to decide about the place of the solvency test in private limited companies. Alongside the examination of legal sources and literature, the authors pursue their research by employing the systematic and teleological analysis of distribution rules under the Croatian Companies' Act. That act has already introduced the 'circumstances test' as a yardstick for the assessment of the validity of the decision to withhold dividend payment. After the introduction, the second part of the paper considers the concept of legal capital and provides an overview of potentially more efficient means of creditor protection. The third part analyses the Croatian legal capital regime, aiming at revisiting it in light of the solvency test. This part examines various solvency tests so as to decide which one could align with the Croatian distribution rules. The fourth part summarizes and concludes the paper.
\end{abstract}

KEYWORDS: legal capital, balance sheet test, solvency test, dividend distribution, the Codification, the Croatian Companies' Act

\footnotetext{
Kristijan Poljanec, University of Zagreb, Faculty of Economics and Business, Zagreb, Croatia; kpoljanec@efzg.hr.

** Hana Horak, University of Zagreb, Faculty of Economics and Business, Zagreb, Croatia; hhorak@efzg.hr.
} 


\section{INTRODUCTION}

Over the last two decades the concept of legal capital, established by the Second Company Law Directive ${ }^{1}$ and maintained in the Codification, ${ }^{2}$ has received a lot of attention in discussions about prospects of EU company law. The discussions followed mainly as a result of the EU Commission's Action Plan to modernize EU company law, ${ }^{3}$ aiming at simplifying the regime provided under the Second Company Law Directive, or even replacing it with an alternative regime in the long-term. ${ }^{4}$

Since the adoption of the plan, the legal capital rules have faced heavy criticism for being inappropriate and ineffective measures for the protection of creditors' interests. ${ }^{5}$ Many have urged for revisiting the EU capital mainte-

\footnotetext{
1 Second Council Directive 77/91/EEC of 13 December 1976 on coordination of safeguards which, for the protection of the interests of members and others, are required by Member States of companies within the meaning of the second paragraph of Article 58 of the Treaty, in respect of the formation of public limited liability companies and the maintenance and alteration of their capital, with a view to making such safeguards equivalent, (OJ L 26,31/1/1977), pp. 1-13. Hereinafter referred to as the Second Company Law Directive.
}

2 Directive (EU) 2017/1132 of the European Parliament and of the Council of 14 June 2017 relating to certain aspects of company law (codification) (Text with EEA relevance), (OJ L 169, 30/6/2017), ch. IV (Capital maintenance and alteration). Hereinafter referred to as the Codification.

3 Hopt, K.: Comparative Company Law 2018, ECGI Working Paper No. 460/2019, July 2019, [https://dx.doi.org/10.2139/ssrn.3421389], p. 18, available at [https://papers.ssrn.com/ sol3/papers.cfm?abstract_id=3421389], accessed on 04/06/2020. See Communication from the Commission to the Council and the European Parliament - Modernising Company Law and Enhancing Corporate Governance in the European Union - A Plan to Move Forward, Brussels, 21.5.2003, COM/2003/0284 final/, pp. 17-18, available at [https://op.europa.eu/en/publication-detail/-/publication/11f14007-f2d6-4610-9bc4-2402324472f4/language-en]. Hereinafter referred to as AP 2003.

4 AP 2003, pp. 17-18; 24-26. Two documents preceded the plan. In 1999 the SLIM ('Simpler Legislation for the Internal Market') proposal aimed at modest simplification of the EU legal capital rules without leaving the legal capital concept. In 2002 the High Level Group of Company Law Experts assesed the legal capital concept as a costly, inaccurate and inflexible source of equity funding, and suggested its reform in three possible directions: simplification along the SLIM lines, complete abandonment of the concept along the US lines, or elimination of the legal capital accompanied by the introduction of the solvency test. See A Modern Regulatory Framework for Company Law in Europe: A Consultative Document of the High Level Group of Company Law Experts ('Winter Report'), ch. 3, pp. 23-26, available at [https://www. eerstekamer.nl/eu/documenteu/a_modern_regulatory_framework_for/f=/vgklizzpd9we.pdf], accessed 04/06/2020.

5 Critics may mainly be found in the Anglo-American literature. See, among others, Rickford, J. (ed): Reforming Capital, Report of the Interdisciplinary Group on Capital Maintenance, European Business Law Review (EBLR), 15(4) 2004, p. 947, available at [https://www. 
nance regime either by complementing ${ }^{6}$ it or abandoning it in its entirety. ${ }^{7}$ The reformists also hinged their critics upon cases in Centros ${ }^{8}$ Úberseering $^{9}$ and Inspire Art, ${ }^{10}$ which came roughly around the same period of time. In those cases, the Court of Justice of the European Union ${ }^{11}$ referred to the minimum legal capital requirement as an unnecessary and potentially disproportionate means of creditor protection. Such a requirement may preclude unhindered exertion of the freedom of establishment. ${ }^{12}$ Concerning the purportedly protective character of such requirement for creditors, it was suggested that the EU Member States should seek to adopt measures which are less restrictive, or which interfere less with fundamental freedoms by, for example, making it

biicl.org/files/916_capital_maintenance_report_-_final.pdf], accessed on 04/06/2020; Armour, J.: Legal Capital: An Outdated Concept?, European Business Organization Law Review (EBOR), 7(1) 2006, [https://doi.org/10.1017/s156675290600005x], p. 3, available at [https:// papers.ssrn.com/sol3/papers.cfm?abstract_id=910826], accessed 04/06/2020; Ferran, E.: Revisiting Legal Capital, European Business Organization Law Review (EBOR), 20(3) 2019, [https://doi.org/10.1007/s40804-019-00161-z], pp. 525-526, available at [https://papers.ssrn. com/sol3/papers.cfm?abstract_id=3449052], accessed 04/06/2020. Some continental authors have followed suit, among others, Rodés Saldaña, L.: Suitability of EU Legal Capital Rules as a Mechanism of Creditor Protection: A Comparative and Functional Study, Doctoral Thesis, University of Leicester Law School, Leicester, 2019, pp. 57-62.; Jakšić, T.; Petrović, S.: Mogući pravci izmjena i dopuna hrvatskog prava društava, Zbornik Pravnog fakulteta Sveučilišta u Rijeci, 37(3) 2016, pp. 1114-1115. For a comprehensive overview of possible disadvantages of the legal capital rules see also Jovanovič, D.: Svrha temeljnog kapitala u pravima EU, Pravo u gospodarstvu: časopis za gospodarsko-pravnu teoriju i praksu, 48(2) 2009, pp. 508; 513-518.

6 Rodés Saldaña, op. cit. (n. 5), p. 114; Jovanovič, op. cit. (n. 5), pp. 539-542.

7 Rickford, op. cit. (n. 5), pp.921; 986; Armour, op. cit. (n. 5), p. 3.; Hopt, op. cit. (n. 3), p. 29.; Ferran, op. cit. (n. 5), p. 542; Rodés Saldaña, op. cit. (n. 5), p. 114.

8 Judgment of the Court of 9 March 1999, Centros Ltd v Erhvervs- og Selskabsstyrelsen, C-212/97, EU:C:1999:126. For detailed overview of the case see, among others, Horak, H. et al., European Market Law: Handbook, Vol. 1, Voronezh/Zagreb, 2014, pp. 214-225; Horak, H.; Dumančić, K.; Šafranko, Z.: Sloboda poslovnog nastana trgovačkih društava u pravu Europske unije, Ekonomski fakultet Zagreb, 2013, pp. 20-22, available at [http://www.efzg.unizg. hr/userdocsimages/PRA/2017\%20-\%20novi\%20web/Publikacije/SLOBODA\%20POSLOVNOG\%20NASTANA.pdf], accessed 09/06/2020.

9 Judgment of the Court of 5 November 2002, Überseering BV v Nordic Construction Company Baumanagement GmbH (NCC), C-208/00, EU:C:2002:632. For detailed overview of the case see, among others, Horak et al., Sloboda..., pp. 22-24; Horak et al., European..., pp. 226243.

10 Judgment of the Court of 30 September 2003, Kamer van Koophandel en Fabrieken voor Amsterdam v Inspire Art Ltd, C-167/01, EU:C:2003:512. For detailed overview of the case see, among others, Horak et al., Sloboda..., pp. 24-26.

11 Hereinafter referred to as the CJEU.

12 Centros, paras. 35-37; Überseering, para. 93; Inspire Art, paras. 42; 135. 
possible in law for public creditors to obtain necessary guarantees. ${ }^{13}$ Thereby, as some argue, the CJEU accelerated the dilution of minimum capital requirements in national company laws. ${ }^{14}$

Notwithstanding the aforementioned critics, the institutional attempts to revisit the EU capital maintenance regime have not yielded much result. The proposal for a regulation of a European Private Company (Societas Privata Europaea) ${ }^{15}$ sought to relax the legal capital concept by introducing a minimum capital requirement of 1 EUR and a solvency statement. However, it failed following the Member States' ${ }^{16}$ and the EU Parliament' ${ }^{17}$ dissenting opinions on a minimum capital requirement. Moreover, the latest 'codification' of EU company law has not revisited the traditional mandatory capital maintenance regime. It has remained practically intact ever since the EU introduced it in $1976 .{ }^{18}$ It follows that, for the time being, any discussion on introducing alternative or complementary means of creditor protection, including solvency test, remains confined to the Member States' domain. Such state-of-the-art allows for divergent legal solutions dependent on national legal traditions.

Building their paper around critics of the EU capital maintenance regime, the second part presents the concept of legal capital and provides an overview of other purportedly more effective means of creditor protection. A broad array of additional safeguards may encompass several contracts, property, and company law safeguards. The paper, however, does not pretend to delve into all potentially more effective means of creditor protection, as they rely on the inventiveness of the business practice. It rather intends to present the most debated ones. Moreover, the analysis carried out will be confined to the legal per-

13 Centros, para. 37.

14 Ferran, op. cit. (n. 5), p. 522.

15 Proposal for a Council Regulation on the statute for a European private company \{SEC(2008) 2098\} \{SEC(2008) 2099\}/COM/2008/0396 final - CNS 2008/0130/, available at [https://eur-lex.europa.eu/legal-content/EN/TXT/?qid=1591291995560\&uri=CELEX:52008PC0396], accessed on 04/06/2020. Hereinafter referred to as the SPE Proposal.

16 [https://www.worker-participation.eu/Company-Law-and-CG/Company-Law/European-Private-Company-SPE], accessed on 02/06/2020.

17 The Commitee on Legal Affairs of the EU Parliament suggested that the minimum capital of 1 EUR should have been reserved only for companies that would apply the solvency test. Otherwise the minimum capital should have been 8,000 EUR. See more on the proposal in Siems, M.; Herzog, L.; Rosenhäger, E.: The European Private Company (SPE): An Attractive New Legal Form of Doing Business?, Butterworths Journal of International Banking and Financial Law, February 2009, pp. 10-11, available at [https://papers.ssrn.com/sol3/papers. cfm?abstract_id=1350465], accessed 04/06/2020.

18 Rodés Saldaña, op. cit. (n. 5), p. 23. 
spective. The accounting perspective, most notably the impact of the fair value accounting standard on the legal capital maintenance, shall be considered only to the extent necessary for a comprehensive understanding of the matter, as more elaborated discussion would go beyond the scope of the paper. ${ }^{19}$

In the third part, the authors carry out an assessment of the Croatian capital maintenance regime in light of the foregoing considerations so as to consider a possibility of introducing a solvency test as a yardstick for prudent dividend distribution. Alongside the examination of legal sources, case law, and literature, the authors employ a systematic and teleological analysis of distribution rules under the Croatian Companies' Act. The discussion on the role of the solvency test will be confined only to dividend payment as the most common type of capital distribution. However, the findings of this part could apply mutatis mutandis to other types of distributions. ${ }^{20}$

The paper seeks to find out whether and to what extent a solvency test could be introduced into Croatian law de lege ferenda. The authors build their research around earlier attempts to revisit the prescriptive minimum capital rules under Croatian company law, and related suggestions to replace it with a 'payment test'. ${ }^{21}$ It is argued that the EU regime would allow the introduction of such a test into Croatian law on public limited companies as a distribution test complementary to the two-fold 'balance sheet test'. However, it remains the national legislator's sole discretion to decide about the place of the solvency test in private limited companies. As solvency tests differ, this part of the paper takes stock of variant forms of solvency tests to decide which one could best align with the Croatian rules. The fourth part summarizes and concludes the paper.

19 For a more elaborated discussion on the interaction between capital safeguards and financial reporting standards see Horak, H.; Poljanec, K.: Fighting Short-Termism in EU Company Law after the Financial Crisis, European Company Law (EUCL), 17(4), 2020, pp. 117119 , available at [https://kluwerlawonline.com/journalarticle/European+Company+Law/17.4/ EUCL2020018], accessed on 03/08/2020.

20 Distributions should be understood broadly: dividends, purchase or redemption by the company of its own shares (share buy-backs), or alterations in company's capital in relation to transfers of assets to shareholders (reduction of capital). Rickford, op. cit. (n. 5), pp. 922-923.

${ }^{21}$ Jakšić; Petrović, op. cit. (n. 5), p. 1115. 


\section{CONCEPT OF LEGAL CAPITAL AND THE ALTERNATIVES THEREOF}

\subsection{THEORY OF CAPITAL MAINTENANCE}

The concept of legal (share, nominal) capital belongs to the continental company law tradition. ${ }^{22}$ Broadly speaking, the continental concept is built around two blocks of rules. ${ }^{23}$ On the one hand, there are rules on minimum share capital, imposing an obligation on the shareholders to pay up some minimum equity into the company. ${ }^{24}$ In return, they will be vested with the limited liability privilege ${ }^{25}$ and a share in the nominal capital. ${ }^{26}$ This rule is coupled with the theory of capital maintenance. The theory imposes an obligation on the company to maintain and protect a nominal amount of net assets of an amount equivalent to the paid-up minimum capital against distribution to the shareholders. ${ }^{27}$ Such capital should be considered as available for doing business; however, it should be not distributed to the shareholders unless special mechanisms of creditor protection are put in place, or the company is being wound up..$^{28}$

By imposing such constraints, capital maintenance rules serve various functions. There is a wide consensus that those rules primarily secure creditors' rights. ${ }^{29}$ It is argued that legal capital rules may secure creditors against the risk of mindless acts by the shareholders, which may lead to the reduction of the company's assets, making the company more vulnerable to insolven-

\footnotetext{
22 Jovanovič, op. cit. (n. 5), p. 507; Hopt, op. cit. (n. 3), p. 28.; Armour, op.cit. (n. 5), p. 2.

23 Rodés Saldaña, op. cit. (n. 5), p. 22.

24 Rickford, op. cit. (n. 5), p. 937.; Barbić, J.: Pravo društava. Knjiga Druga. Društva kapitala. Svezak I.: Dioničko društvo, Peto, izmijenjeno i dopunjeno izdanje, Organizator, Zagreb, 2010, p. 31.

25 Armour, op. cit. (n. 5), p. 10.

26 Barbić, op.cit. (n. 24), p. 31.

27 Rickford, op. cit. (n. 5), p. 937; Barbić, op. cit. (n. 24), p. 44; Maurović, Lj.: Directive 2006/68/EC Amending the Second Company Law Directive EU as Regards the Maintenance of Public Limited Liability Companies' Capital and the Acquisition of Own Shares, 2013, [https://dx.doi.org/10.2139/ssrn.2237882], p. 12. Available at [https://papers.ssrn.com/sol3/papers.cfm?abstract_id=2237882], accessed on 04/06/2020.

28 Rickford, op. cit. (n. 5), p. 928.

29 Winter Report, p. 23; Rickford, op. cit. (n. 5), p. 931; Jovanovič, op. cit. (n. 5), p. 507; Armour, op. cit. (n. 5), p. 2; Rodés Saldaña, op. cit. (n. 5), p. 1.; Ferran, op. cit. (n. 5), p. 528. However, the concept of fixed per value (accountable per value) shares assigns certain nominal value to every single share representing part of the share capital. Thereby, it also protects the shareholders against dilution of their rights. Winter Report, p. 23.
} 
cy. ${ }^{30}$ The rules are supposed to protect the creditors against excessive distributions,${ }^{31}$ and prevent the company's insolvency. ${ }^{32}$ Moreover, legal capital rules could prevent the reduction of the expected value of creditors' claims, even if shareholders' demeanor will not result in insolvency. ${ }^{33}$ Therefore, legal capital rules are supposed to enable creditors to rely on the fact that the equity is going to be maintained as a sort of set 'guarantee' to meet their claims unless reduced in the regular course of business. ${ }^{34}$

By adopting prescriptive legal capital rules, the EU capital maintenance regime has decided to follow the theory of legal capital concerning the public limited liability companies (PLCs). Being under the German influence, ${ }^{35}$ its principal goal is to secure creditors ${ }^{36}$ by introducing a minimum capital requirement of $25000 \mathrm{EUR},{ }^{37}$ along with a set of various capital maintenance and alteration rules. ${ }^{38}$ The system of capital distributions ${ }^{39}$ is based exclusively on an ex ante

\footnotetext{
30 Armour, op. cit. (n. 5), p. 6; Rodés Saldaña, op. cit. (n. 5), p. 3.

31 Rodés Saldaña, op. cit. (n. 5), p. 1.; Ferran, op. cit. (n. 5), p. 528.

32 Rodés Saldaña, op. cit. (n. 5) p. 38.

33 Armour, op. cit. (n. 5), p. 6.
}

34 Rickford, op. cit. (n. 5), p. 928. In case of mistatements in prospectus, a shareholder may seek damages in the form of a return of the amount equal to the amount he originally paid for the contested shares in the secondary market, and ask the company to take those shares back. Given that the provisions of the Second Company Law Directive serve to regulate only internal relations between an investee company and an investor, and not disputes arising from a regular sale contract, those rules do not contravene national provisions on civil liability for damages even if, it seems, damages litigation would imply the return of the amount equal to the original share purchase price and share redemption. Such return is not a return of the paid-in amount. It represents the investee's civil law obligation to compensate the investor for damages he suffered in the course of regular (non-transparent, though) course of business. Such a 'share buy-back' does not aim to undermine the share capital. Hence, the corresponding return of the original share price to the investor does not constitute unlawful distribution. See Judgment of the Court (Second Chamber), Alfred Hirmann v Immofinanz AG, C-174/12, EU:C:2013:856, paras. 27, 28, 31 and 32. See more in Horak, H.; Dumančić, K.; Poljanec, K.: Modernizacija i usklađivanje prava društava u Republici Hrvatskoj sa pravnom stečevinom Europske unije i načelo transparentnosti podataka, in Zbornik radova: II. Međunarodna konferencija Bosna i Hercegovina $i$ euroatlantske integracije. Trenutni izazovi i perspektive, Bihać, 2014, pp. 582-587.

35 Rodés Saldaña, op. cit. (n. 5), p. 44.

36 Codification, recital 40.

37 Codification, Art 45. para. 1.

38 Codification, ch. IV.

39 The term 'distribution' refers in particular to the dividend payment and payment of interests relating to shares. See Codification, Art. 56 para 4. Such a non-exhaustive wording suggests that 'distribution' may include any other mean of capital returns to the shareholders, e.g. acquisition of the company's own shares (share buy-backs) and capital reductions (capital 
'two-fold' balance sheet test. It consists of the enhanced net asset test ${ }^{40}$ and accumulating running account profits test ('partial earned surplus test'). ${ }^{41}$ The enhanced net asset test is based on the premise that no distribution to shareholders may be executed when on the closing date of the last financial year the net assets as set out in the company's annual accounts are or, following such a distribution, would become, lower than the amount of the subscribed capital plus undistributable legal or statutory capital reserves. ${ }^{42}$ Besides, the amount intended for distribution may not exceed the profits at the end of the last financial year plus any profits brought forward and sums drawn from reserves available for this purpose, less any losses brought forward and sums placed to reserve in accordance with the law or the statutes. ${ }^{43}$

The rationale behind the balance sheet test is to assure the creditors that the minimum subscribed capital and mandatory reserves (in fact, the equivalent net assets) shall not be distributed to shareholders in the course of trading but maintained in the company. ${ }^{44}$ The regime, however, applies only to PLCs. ${ }^{45}$ There is virtually no harmonization of rules on the creditor protection in relation to private companies. ${ }^{46}$ Such an approach implies that the Member States are allowed to design their own rules on the asset distribution in private limited liability companies (LLCs). Many of them, including Germany, significantly relaxed the capital maintenance rules with regard to private limited liability companies (mini GmbHs/simple LLCs). It should be also noted that the harmonized rules on capital maintenance with regard to PLCs provide only

writing-downs). Therefore, the concept of distribution, as provided in the Codification, is a broad one. It covers at least dividend distribution and interest payment regulated by the general rules on distribution (Codification, arts 56-58), companies' acquisitions of their own shares or share buy-backs (Codification, arts. 59-67), and capital reduction (Codification, arts. 68-83).

40 Rickford, op. cit. (n. 5) pp. 982, 1002.

${ }^{41} \quad$ Ibid., pp. 969; 1002. 'Partial' due to the fact that under the Second Company Law Directive share premiums were not considered as undistributable share capital but rather distributable capital reserves. Ibid., pp. 983; 1002.

42 Codification, Art. 56 para. 1.

43 Codification, Art. 56 para. 3.

44 Rodés Saldaña, op. cit. (n. 5), pp. 54-55.

45 Codification, Art. 44 in conjunction with Annex I.

46 Gerner-Beuerle C. et al.: Study on the Law Applicable to Companies Final Report, Directorate-General for Justice and Consumers (European Commission) and the London School of Economics and Political Sciences, June 2016, p. 221, available at [https://op.europa.eu/en/publication-detail/-/publication/259a1dae-1a8c-11e7-808e-01aa75ed71a1], accessed on 04/06/2020. Hereinafter referred to as the Company Law Study. However, Germany decided to extend the scope of the Codification to private limited companies ('GmbHs'). 
for a minimum protection of creditors, ${ }^{47}$ meaning that EU Member States are allowed to introduce additional, complementary safeguards for asset distribution with regard to PLCs. Various options in this regard will be in the focus of the following parts of the paper.

\subsection{THE THEORY MEETS CRITICS}

Apart from the Germans, who favor the present rules-based approach concerning PLCs, ${ }^{48}$ most academic literature has challenged the merits of the existing EU capital maintenance regime for PLCs, considering it inappropriate for securing creditor protection. Several key points are worth considering here.

\subsubsection{SHARE CAPITAL AS FICTITIOUS GUARANTEE}

The fact that the founders of the company once invested a certain amount of equity capital into the company does not mean that the same amount has remained in the company, or that the net assets structure has not altered over time. ${ }^{49}$ The fixed, nominal amount declared in the court register on company formation (or subsequent capital increase) does not necessarily reflect the actual amount or value of the company's assets at the time the money is advanced to the company ${ }^{50}$ However, what does matter to the creditors is the company's actual net assets structure. ${ }^{51}$ In simple terms, no 'guarantee' function can be associated with the share capital. ${ }^{52}$ A voluntary ('adjusting') creditor (e.g. banks or suppliers) would need to refer to the company's overall financial statements to get a real impression of the company's financial viability. ${ }^{53}$ As voluntary creditors pay attention to the insolvency risks and the future cash flows rather than to the historic capital contributions, this security measure is therefore not tailored to the actual commercial needs ${ }^{54}$ and has no reasonable link to the company's long term financial viability ${ }^{55}$ What the legal capital rules, how-

\footnotetext{
47 Codification, recital 3.

48 Rodés Saldaña, op. cit. (n. 5), p. 61.

49 Barbić, op.cit. (n. 24), p. 42.

50 Armour, op.cit. (n. 5), p. 10.

51 Barbić, op. cit. (n. 24), p. 41.

52 Winter Report, p. 23; Barbić, op. cit. (n. 24), p. 41; Jakšić; Petrović, op. cit. (n. 5), p. 1114.

53 Rodés Saldaña, op. cit. (n. 5), p. 60.

${ }_{54}$ Winter Report, p. 24; Rickford, op. cit. (n. 5), p. 938.; Ferran, op. cit. (n. 5), pp. 528-529.

55 Winter Report, p. 25; Rickford, op. cit. (n. 5), p. 938.; A KPMG study commissioned by the EU Commission in 2006 revealed that EU companies did not consider the EU legal cap-
} 
ever, can do is to force the shareholders to pay-up and keep the equity once invested as share capital. ${ }^{56}$ Moreover, they can prevent excessive asset distributions. ${ }^{57}$ Nonetheless, they cannot prevent a company from becoming insolvent due to bad market conditions, directors' wrongs, or shareholders' mindless behavior. ${ }^{58}$ As for the involuntary ('non-adjusting') creditors (e.g. tort victims or the State), the tortfeasor's minimum share capital paid on formation is not of much use for satisfying their claims by the time when the cause of action takes place. Instead, they hope for third-party liability insurances. ${ }^{59}$ The additional objection regarding the function of the legal capital rules comes from the fact that the amount of the EU minimum capital has remained unrevised for the last forty years, and hence might have completely lost its purpose over time due to changing economic and monetary trends in the EU. ${ }^{60}$ Therefore, on the one hand, legal capital rules are of little use for the creditors, as they do not commensurate with their actual needs, and, on the other hand, are taxing for controlling shareholders and/or directors of big public companies, who receive scarce dividends. ${ }^{61}$

ital rules as being of much practical relevance for the assessment of viability of a company. They relied instead to figures such as 'net equity' and 'market capitalisation'. KPMG Feasibility Study on an Alternative to the Capital Maintenance Regime Established by the Second Company Law Directive 77/91/EEC of 13 December 1976 and an Examination of the Impact on Profit Distribution of the new EU-accounting Regime: Main Report, p. 2. Available at [https://lse.rl.talis.com/items/0FE92D26-066F-2FD8-C723-2B5F1B5F28D1.html], accessed on 04/06/2020. Hereinafter referred to as the KPMG Study. However, it was argued that share capital was necessary for equity financing, and that it did not constitute a barrier to the distribution of excess capital. Ibid., p. 3. Moreover, the administrative costs of the systems maintained under the recast Second Company Law Directive were not considered high. Thus, costs item did not seem to play a key role in determining whether the transition to an alternative model would actually benefit EU businessess by reducing administrative burdens. Ibid., p. 6.

56 Barbić, op. cit. (n. 24), p. 46-47.

57 Ibid., p. 47; Rodés Saldaña, op. cit. (n. 5), p. 38.

58 Rodés Saldaña, op. cit. (n. 5), p. 38.; Likewise Jovanovič, op. cit. (n. 5), p. 518; Barbić, op. cit. (n. 24), p. 45.

59 Rickford, op. cit. (n. 5), p. 932; Armour, op. cit. (n. 5), pp. 12-13.

60 The EU institutions should consider revisiting the minimum capital requirement every five years. Codification, Art. 45, para. 2. For an extensive analysis of this problem see Rodés Saldaña, op. cit. (n. 5), pp. 50-53.

${ }^{61}$ Hopt, op. cit. (n. 3), p. 29, and the authors cited therein. 


\subsubsection{SHARE CAPITAL AS DISPROPORTIONATE INCORPORATION DETERRENT}

Scarcity of sufficient resources to meet the prescriptive minimum capital requirement might deter individuals, including small and medium-sized entrepreneurs (SMEs), from engaging in entrepreneurial activity and gaining access to limited liability. ${ }^{62}$ Such a discouraging effect of national legal capital rules has led over the years to major capital outflows from continental jurisdictions to the UK. Instead of incorporating their business at home, small entrepreneurs had decided to incorporate their businesses as private companies in the UK, where legal capital rules for such companies were considered less restrictive. ${ }^{63}$ In the aftermath of Centros, Úberseeing, and Inspire Art cases, countries such as France, Germany, Spain (and Croatia, following the Germans) have engaged in defensive corporate lawmaking and significantly reduced the minimum capital requirement for private companies ${ }^{64}$ to prevent local SMEs from moving their businesses abroad. ${ }^{65}$

\subsubsection{SHARE CAPITAL AS A MECHANISTIC DISTRIBUTION YARDSTICK}

The present concept of EU legal capital rules may also be considered too mechanic and hence detached from the company's actual economic prospects. The 'undistributable reserve' concept ${ }^{66}$ of the balance sheet test relies solely on the company's financial accounts, leaving non-accounting parameters (e.g.

\footnotetext{
62 Winter Report, p. 25; Armour, op.cit. (n. 5), p. 11.

63 Armour, op. cit. (n. 5), p. 3.

64 Ringe, W. G.: Corporate Mobility in the European Union - A Flash in the Pan? An Empirical Study on the Success of Lawmaking and Regulatory Competition, Ringe, Oxford Legal Studies Research Paper No. 34/2013; European Company and Financial Law Review 2013; Oxford Legal Studies Research Paper No. 34/2013; University of Oslo Faculty of Law Research Paper No. 2013-19, 2013, [https://doi.org/10.2139/ssrn.2291860], pp. 8-11, available at [https://ssrn.com/abstract=2247323], accessed 09/06/2020; Horak, H.; Dumančić, K.; Šafranko, Z.: Komparativni osvrt na jednostavno društvo s ograničenom odgovornošću, Pravo i porezi, 22 (4), 2013, p. 37; Jakšić, Petrović, op. cit. (n. 5), p. 1110-1112.
}

65 About the origin of the phenomenon of 'regulatory arbitrage' see, among others, Armour, op.cit. (n. 5), p. 17; Bratton, W. W.; McCahery, J. A.; Vermeulen, E. P. M.: How Does Corporate Mobility Affect Lawmaking?, ECGI - Law Working Paper No. 91/2008; Georgetown Law and Economics Research Paper No. 1086667; Amsterdam Center for Law \& Economics Working Paper No. 2008-01, 2008, [https://doi.org/10.2139/ssrn.1086667], pp. 3-37, available at [https:// ssrn.com/abstract=1086667], accessed 09/06/2020; Horak et al., op. cit. (n. 64), p. 37; Ringe, op. cit. (n. 64), pp. 2-39.

66 Rickford, op. cit. (n. 5), p. 938; Rodés Saldaña, op. cit. (n. 5), p. 55. 
future cash flow, expected market conditions, off-balance items such as prospective and contingent liabilities, etc.) outside its scope. ${ }^{67}$ Such a mechanical ${ }^{68}$ approach may lead to a company being prejudiced from paying dividends notwithstanding the fact that it is actually capable of paying dividends without compromising its solvency prospects. ${ }^{69}$ On the other hand, restrictions on distributions are ill-targeted for big companies having rather modest minimum capital. Such companies may easily satisfy the mandatory (though completely inapt) level of undistributable capital and still engage in excessive dividend payment. $^{70}$

Deficiency of heavily relying on financial accounts has gained particular traction after the adoption of the fair value international financial reporting standard/ accounting standard (IFRS/IAS no. 13) for financial statements. ${ }^{71}$ The fair value measurement relies on re-measurements following changes in relevant market prices or equivalent measurement parameters. ${ }^{72}$ It fluctuates and does not reflect the fundamental value of a specific asset. ${ }^{73}$ This standard is particularly inappropriate for declaring the actual value of financial assets in situations of high market instability, as it introduces volatility into the company's financial statements, including the balance sheet, resulting in the recording of unrealized profits and losses. ${ }^{74}$ Such volatility, even if it reflects actual variations in assets value, might, however, not be realized in the short term, and can be only of temporary nature. On the other hand, recording of unrealized losses may further lead to the reduction of share capital below the lower threshold and force shareholders to implement measures such as re-capitalization, or even company dissolution, in spite of the fact that the company as such is not insolvent, ${ }^{75}$ and the 'losses' recorded

67 Along the same lines Rodés Saldaña, op. cit. (n. 5), p. 55. Rickford argues that the net assets test is to be operated strictly by reference to company's accounts while it is less clear whether the earned surplus test is supposed to operate along the same lines. See Rickford, op.cit. (n. 5), p. 938.

68 Rickford, op. cit. (n. 5), p. 938.

69 Rodés Saldaña, op. cit. (n. 5), p. 55.

70 Jovanovič, op. cit. (n. 5), p. 518.

71 Regulation (EC) No 1606/2002 of the European Parliament and of the Council of 19 July 2002 on the application of international accounting standards, (OJ L 243, 11/9/2002), pp. 1-4.

72 KPMG Study, p. 7.

73 Strampelli, G.: The IAS/IFRS After the Crisis: Limiting the Impact of Fair Value Accounting on Companies' Capital, European Company and Financial Law Review, De Gruyter, 8(1) 2011, [https://doi.org/10.1515/ecfr.2011.1], pp. 3-4, available at [https://ideas.repec.org/a/bpj/ eucflr/v8y2011i1p1-29n1.html], accessed on 04/06/2020.

74 Ibid., p. 4.

75 Ibid., p. 5. 
do not correspond to the real devaluation in company's assets. ${ }^{76}$ In simple terms, the fair value approach is problematic for the calculation of distributable profits, as it produces the gap between the company's real capacity to pay distributions and the outcome under the applicable accounting standard. ${ }^{77}$ It somehow distorts the balance sheet test, making the results either too generous (in case of assets' overestimation) or too restricted (in case of assets' underestimation), and that does not reflect the actual prospects of solvency. ${ }^{78}$ The accounting standards are simply not intended to serve as a basis for a distribution policy ${ }^{79}$ and have come under a lot of strain recently. ${ }^{80}$

\subsection{OTHER MECHANISMS OF CREDITOR PROTECTION IN PUBLIC LIMITED COMPANIES}

Doubts rose about the practical meaning of the present EU legal capital rules have prompted ideas on the possibility of introducing less mechanical and more 'commercial' mechanisms of creditor protection in cases of capital distributions. The following subchapters shall focus on common contractual, property, and corporate means of creditor protection, where special regard shall be given to the solvency test.

\subsubsection{CONTRACTUAL AND PROPERTY MECHANISMS}

As has been stated earlier, the legal capital rules do not distinguish voluntary from involuntary creditors but impose a 'one-size-fits-all' approach on all stakeholders of the debtor company (erga omnes approach). ${ }^{81}$ Such an implied collective covenant ${ }^{82}$ does not, however, take into consideration the specific needs of certain creditors. Therefore, the practice has turned to tailor-made solutions at the intersection of contract and property law.

\footnotetext{
76 Ibid., p. 11.

77 Jovanovič, op. cit. (n. 5), p. 508; Rickford, op. cit. (n. 5), p. 938.

78 Rickford, op. cit. (n. 5), p. 938.

79 KPMG Study, p. 7.

80 On the need to revisit the current accounting regime see in Strampelli, op. cit. (n. 73), p. 11.; Klein, I.: A Change in Accounting, A Change in Law, Delaware Journal of Corporate Law (DJCL), 42(1) 2017, pp. 20-23, available at [https://papers.ssrn.com/sol3/papers.cfm?abstract_ id=2840968], accessed on 04/06/2020.

81 Rodés Saldaña, op.cit. (n. 5), p. 88.

82 Armour, op.cit. (n. 5), p. 8.
} 
As far as voluntary ('adjusting') creditors are concerned, they mostly rely on private contractual safeguards rather than on mandatory legal capital rules. ${ }^{83}$ Such practice is widely spread across Anglo-American jurisdictions, and not unfamiliar (however, less usual) in continental Europe. Powerful creditors such as banks mostly contract for protection to prevent potentially risky investments by the shareholders. Financial covenants in bank loans usually impose distribution restrictions upon the debtor company either directly - by tying dividend payments to the company's net earnings,${ }^{84}$ - or often indirectly - by asking the company to maintain a certain level of liquidity (level of cash-flow), profitability, net assets, ${ }^{85}$ a certain financial ratio (relation of net assets to debt), etc. ${ }^{86}$

Alongside the bank covenants, voluntary creditors can contract for third-party guarantees, ${ }^{87}$ letters of comfort, or charges. Third-party guarantees will often come in a form of suretyship or bank guarantee. The latter is considered by the case law as an efficient alternative to the mandatory rules on creditor protection. ${ }^{88}$ Likewise, the creditor's loan provided to the debtor company may be secured utilizing a 'strong' letter of comfort. Here a third party (the issuer, usually a parent company) takes an enforceable obligation (unilateral promise) to provide assistance (e.g. by transferring funds, commodities, or inventions; by increasing capital, etc.) to the debtor company (usually a daughter company) to help the company gaining and maintaining liquidity needed to meet the creditor's claims (the letter's recipient, usually a bank) as they fall due. Unlike suretyship, the third party is bound only to keep the given promise and act accordingly, but shall not be considered liable for direct payment of the credit in case of the debtor company's default. ${ }^{89}$

\footnotetext{
83 Jovanovič, op. cit. (n. 5), p. 514.

84 Armour, op. cit. (n. 5), p. 8.

85 KPMG Study, p. 95 (Poland); p. 115 (Sweden).p. 181 (Delaware); p. 199 (California), p. 234 (Australia); p. 254 (New Zeland).

${ }^{86}$ Ibid., p. 48 (France); p. 74 (Germany); p. 141 (UK); p. 180 (Delaware); p. 214 (Canada).

87 Ibid., p. 74 (Germany)

88 Centros, para 37 (as an alternative to mandatory minimum capital); Judgment of the Court (Grand Chamber) of 25 October 2017, Proceedings brought by Polbud - Wykonawstwo sp. z o.o., C-106/16, EU:C:2017:804, para. 58 (as an alternative to mandatory liquidation). However, issuance of a bank guarantee will often be accompanied by the bank's request to receive in return a corresponding collateral from the debtor company. It is argued that such alternative may be as burdensome for the company as the provisions on the mandatory capital maintenance or liquidation. Markovinović, H.; Bilić, A.: The transfer of a company seat to a different member state in the light of the recent 'Polbud' decision, InterEULawEast: Journal for International and European Law, Economics and Market Integrations, 5(2), 2018, [https://doi.org/10.22598/iele.2018.5.2.3], pp. 117-118.

89 See more in Jakšić, T.: Čvrste pokroviteljske izjave - pravna narav ugovora, predmet $i$ povreda obveze pokrovitelja, stečajni postupak i postupak izvanredne uprave, Zbornik Prav-
} 
In the Anglo-Saxon jurisdictions, a floating charge (in US terms, a floating lien) has developed as a common means of securing corporate loans. ${ }^{90}$ This charge 'floats' over the debtor company's overall (current and future) assets, but enables the debtor to freely dispose of the assets in the regular course of trading until the crystallizing event (e.g. default in payment) occurs. ${ }^{91}$ In 1994 the European Bank for Reconstruction and Development developed an 'enterprise charge' along the lines of the UK floating charge. This model-floating charge is available only to companies ${ }^{92}$ and was intended to serve as a set of boilerplate rules for transition states of South-Eastern Europe..$^{93}$

The bank covenants and charges are available only to major creditors having a significant bargaining power. As far as non-voluntary creditors are concerned, it is argued that their position may be secured by mandatory insurances for tort liability and directors' mandatory insurance policies. ${ }^{94}$ However, imposing mandatory insurances would lead to significant costs for companies, as the insurance premium could be quite high given the potential substantive and personal scope of tort liability. ${ }^{95}$ Such a high market entrance fee would leave SMEs outside the market, and act as a deterrent factor resembling the minimum capital requirement. Therefore, such an approach does not seem an apt means of securing creditors' rights.

\subsubsection{COMPANY LAW MECHANISMS}

Transparency and disclosure of corporate information are considered an instrument of shareholders' protection and control of management and supervisory boards, whereas their purpose in the capital market is to ensure trustworthy and accurate information for the entire market, most notably for the capital

nog fakulteta Sveučilišta u Rijeci, 39(2), 2018, [https://doi.org/10.30925/zpfsr.39.2.3], pp. 775 et seq.

90 Čulinović-Herc, E.: Zalaganje imovine trgovačkih društava: engleski Floating Charge $i$ Enterprise Charge model-zakona o osiguranju potraživanja Europske banke, Zbornik Pravnog fakulteta u Zagrebu, 45(1), 1995, p. 94; KPMG Study, p. 141.

91 Čulinović-Herc, op. cit. (n. 90), pp. 102, 106. The floating charge shall convert into a fixed charge over the assets which are part of the debtor's inventory at the moment of crystallization.

92 Model Law on Secured Transactions, Art. 6.6. Available at [https://www.ebrd.com/whatwe-do/legal-reform/access-to-finance/transactions.html], accessed 15/06/2020.

93 Čulinović-Herc, op. cit. (n. 90), pp. 94; 115-118. On the floating charge under Croatian property law see more in Gavella, N. (ed), Stvarno pravo, Svezak 1., Narodne novine, 2007, pp. 283-291.

94 Rodés Saldaña, op. cit. (n. 5), pp. 83-86.

95 Ibid., p. 87. 
supply-side - potential creditors and investors. However, unlike contractual and property arrangements, those requirements do not serve as a means of direct enforcement of creditors' rights. They serve as ex ante measures, ${ }^{96}$ aiming at creating an atmosphere of mutual trust in the capital market and surveillance over the recipient company's affairs. They enable creditors to reach an informed decision on corporate financing, and, in return, increase the debtor's prospects for getting cheaper loans as the prospects of default risk are made public. ${ }^{97}$ However, the static picture provided by the financial reports, costly and time-consuming processes of checking data, ${ }^{98}$ and heterogeneity of financial reporting caused by the 'opt-in' IFRS reporting regime for certain types of companies $^{99}$ may be considered as the regime's weak points.

Securing creditors' rights may also be achieved through sound corporate governance practices. The EU corporate framework encourages the use of complementary soft law measures which continue to address internal corporate governance matters at the point where the legal act has set a limit. ${ }^{100}$ It promotes the application of corporate governance codes by requiring listed companies to refer in their corporate governance statement to an applicable code and report on its application on a 'comply or explain' basis. ${ }^{101}$ The application of soft law measures requires continuous monitoring by regulatory authorities, which should check whether the declaration of compliance with the recommendations published in the code actually exists, and take action in case of inaccuracies. $^{102}$

\footnotetext{
96 Ibid., p. 80.

97 Ibid., pp. 80-81.

98 Ibid., pp. 81-83.
}

99 Regulation (EC) No 1606/2002 of the European Parliament and of the Council of 19 July 2002 on the application of international accounting standards, (OJ L 243, 11/9/2002), Art. 5 leaves to the Member States the margin to decide whether or not ('may permit or require') to extend the application of the IAS/IFRS to individual annual accounts of publicly traded companies and individual and consolidated accounts of non-publicly traded companies, respectively. Therefore, there is a wide heterogeneity in the EU on how relevant profits in the 'optional' financial statements are determined for dividend-distribution purposes. KPMG Study, p. 320.

100 Barbić, J. et al:: Korporativno upravljanje: osnove dobre prakse vođenja društva kapitala, Zagreb, 2008, p. 93.

101 Directive 2013/34/EU of the European Parliament and of the Council of 26 June 2013 on the annual financial statements, consolidated financial statements and related reports of certain types of undertakings, amending Directive 2006/43/EC of the European Parliament and of the Council and repealing Council Directives 78/660/EEC and 83/349/EEC Text with EEA relevance, (OJ L 182, 29/06/2013), Art. 20 para. 1 (b).

102 Horak H.; Bodiroga Vukobrat, N.: Comply or Explain Experiences of the EU Member States, in: Horak et al., Hrvatsko i europsko pravo društava/Croatian \& European Company Law, Zbornik radova/Collection of Proceedings, p. 40, available at [http://www.efzg.unizg. 
However, the voluntary nature and implementation of soft law measures make them rather weak security against shareholders' and/or directors' rash behavior, comparing to more traditional ex post corporate remedies such as directors' liabilities, restitution of unlawfully paid dividends, or piercing the corporate veil. Directors' liability is a mirror image of the fiduciary duty they owe to the company. Directors, being the company's agents, must primarily act in the best interest of the company. ${ }^{103}$ The duty of care implies they should devote sufficient time, care, and diligence to manage the company while acting on a basis of adequate information. They should possess the necessary skills and experience to reach a sound business decision, and should carefully consider the likely outcome(s) thereof. ${ }^{104}$ By focusing on the company's well-being, they indirectly keep the position of the company's stakeholders (employees, the state, creditors) safe. Nonetheless, they will be held liable in case of a faulty breach of company law principles, which have led to the company's insolvency and, consequently, reduced prospects of meeting the creditors' claims. ${ }^{105}$ Still, at least in continental Europe, the directors shall not be held liable for unlawfully distributed dividends, ${ }^{106}$ as such violations do not stem from the abuse of the board competencies but rather from shareholders' opportunistic conduct. Shareholders remain solely liable for unlawful distributions if they knew or ought to have known the unlawfulness of the distribution received. ${ }^{107}$ Besides, shareholders would also be held liable for the company's liabilities towards the creditors if they engaged in malicious actions aiming at reducing

hr/userdocsimages/PRA/2017\%20-\%20novi\%20web/Publikacije/hrvatsko_i_europsko_pravo_drutava_2.pdf], accessed on 04/06/2020.

103 Agency relationship in corporate governance is defined by the relationship of the principal (shareholder) and his agent (director). The principal entrusts the performance of management tasks to his agent assuming that he, being a professional, will perform the task better so to achieve the desired outcome. See more in Tipurić, D.: Nadzorni odbor i korporativno upravljanje, Zagreb, 2006, p. 96.

104 See Horak, H.; Dumančić K.: Introduction of the Business Judgement Rule into Croatian Legislation, in: Horak et al., Hrvatsko i europsko pravo društava/Croatian \& European Company Law, Zbornik radova/Collection of Proceedings, p. 120, available at [http://www.efzg. unizg.hr/userdocsimages/PRA/2017\%20-\%20novi\%20web/Publikacije/hrvatsko_i_europsko_pravo_drutava_2.pdf], accessed on 04/06/2020; Gerner-Beuerle, C.; Paech, P.; Schuster, E. P.: Study on Directors Duties and Liability, London School of Economics and Political Scienes, London, April 2013, p. 11, available at [http://eprints.lse.ac.uk/50438/1/__Libfile_ repository_Content_Gerner Beuerle,\%20C_Study\%20on\%20directors\%E2\%80\%99\%20duties\%20and\%20liability(lsero).pdf], accessed 06/07/2020.

105 Rodés Saldaña, op. cit. (n. 5), pp. 88; 90.

106 Ibid., p. 93.

107 Ibid., p. 91. 
the company's prospects of meeting the creditors' claims. ${ }^{108}$ Both remedies serve as civil-law safeguards for the restitution of the share capital to the company and provide more chances for the actual enforcement of the creditors' right. A problem, however, may arise at the litigation level, as directors' fault and shareholders' unfair demeanor is hard to prove. It seems even harder to pierce the legal personality veil, as courts are mostly wary about making the shareholders liable for the company's debts. ${ }^{109}$

\subsubsection{SOLVENCY TEST}

Stand-alone balance sheet test under the traditional capital maintenance rules does not reflect a true commercial position of the company ('trading solvency') but rather a 'balance sheet solvency'. The 'balance sheet solvency' relies heavily on current financial indicators, i.e. on-the-balance-sheet items, leaving, however so-called off-the-balance-sheet-items completely out of sight (most notably, business prospects of the company). On-the-balance-sheet items are, moreover, highly dependent on the controversial fair value accounting method, which may result in underestimation or overestimation of the on-the-balance-sheet items, and therefore negatively influences both the financial sustainability of the company and shareholders' legitimate expectations to receive the dividend. Therefore, the balance sheet test is a mechanical, unreliable, and even detrimental restriction on dividend distribution. Private law mechanisms have also shown certain weaknesses. They are either reserved for major creditors, voluntary, or difficult to enforce. Therefore, in order to overcome the disadvantages of the balance sheet test, national legislators should seek for a distribution yardstick that will not rely solely on the accounting numbers entered on the balance sheet of the company's annual financial statements but would rather ask directors to assess ex ante the potential outcomes of the intended distribution in light of the actual economic surroundings of the company, where special regard should be given to the company's solvency prospects. The solvency assessment should, moreover, render the directors liable in the case where no reasonable economic grounds for dividend distribution existed, resulting in compromising the company's solvency.

Anglo-American company laws $\mathrm{s}^{110}$ have undertaken far the biggest step towards introducing solvency standards into dividend distribution schemes. Under US law, the distribution shall not take place if, after giving it effect, the company would not be able to meet its debts as they fall due in the regular course of

108 Ibid.

109 Ibid., p. 92.

110 Save for British law, which has followed the EU regime. 
trading. ${ }^{111}$ Moreover, a proposed distribution must meet the balance sheet test requiring that, following the distribution, assets must equal or exceed liabilities plus any amount needed to meet preferential shareholders' claims if the company were to be dissolved at the time of distribution. ${ }^{112}$ Application of such test is underpinned by directors' personal liability for payment of excessive dividend. ${ }^{113}$ Hence, unlike under the continental regime, a company operating under US law shall rely on the twofold cumulative (trading/cash flow) solvency and simple (bare) net asset test (balance sheet solvency). ${ }^{114}$ Such a regime makes it harder for US companies to distribute dividends, as they should meet a double burden test. Not just that a company has to meet the balance sheet requirements but the board should also know whether the company will be able to meet its liabilities following the distribution. However, no concerns have been raised yet with regard to this system. In fact, the MBCA-like distribution rules were adopted in Canadian, ${ }^{115}$ Australian, ${ }^{116}$ and New Zealand legislation. ${ }^{117}$ Hence, the US model of the twofold cumulative solvency test,

111 Model Business Corporation Act (2016 Revision), December 9, 2016, § 6.40 (c) (1). Available at [https://www.americanbar.org/content/dam/aba/administrative/business_law/corplaws/2016_mbca.authcheckdam.pdf], accessed 13/06/2020. Hereinafter referred to as the MBCA. This act serves as a model for the states to frame their own state corporation laws. KPMG Study, p. 155.

112 MBCA, § 6.40 (c) (2).

113 MBCA, $\S \S 8.30$ and 8.33. See more details in Rickford, op. cit. (n. 5), pp. 1017-1018; Rodés Saldaña, op.cit. (n. 5), p. 40.

114 Rickford, op. cit. (n. 5), p. 969. The concept of legal capital does not serve as a means of creditor protection in state corporation acts either. California completely abandoned legal capital rules and par value shares. Two other models - New York and Delaware - are less extreme. Both have retained legal capital rules (in particular, par value shares) but not for the purposes of creditor protection. Besides, New York has retained a modest minimum capital requirement. Rickford, op. cit. (n. 5), pp. 1019, 1021; Rodés Saldaña, op. cit. (n. 5), pp. 40-41. Instead, creditors usually rely on surplus and net profit tests (Delaware), liquidity test and balance sheet tests (California), alongside self-regulated contractual arrangements such as loan covenants, anti-fraud laws, lifting the corporate veil theory, and bankruptcy codes. Rickford, op. cit. (n. 5), pp. 1020-1022; Rodés Saldaña, op. cit. (n. 5), pp. 41.; KPMG Study, pp. 167-188.

115 See Canada Business Corporations Act, R.S.C., 1985, c. C-44 (last amended January 1, 2020), § 42. Available at [https://laws-lois.justice.gc.ca/PDF/C-44.pdf], accessed 16/06/2020. See more in Rickford, op. cit. (n. 5), p. 1023; KPMG Study, p. 207.

116 See the Corporations Act 2001, No. 50, 2001, Compilation No. 81, Vol. 1, September 28, 2017, § 254T. Available at [https://www.legislation.gov.au/Details/C2017C00328/Download], accessed 16/06/2020. Australia relies on the solvency test accompanied by the earned surplus (operating profit) test, as dividend may be paid only out of profits. KPMG Study, pp. 222-223. Ferran, op. cit. (n. 5), p. 541.

117 The Companies Act 1993, No. 105, September 28, 1993, § 4. Available at [http://www.legislation.govt.nz/act/public/1993/0105/latest/DLM319998.html], accessed 16/06/2020. Besides, 
alongside the solvency certificate, stands for a common Anglo-American alternative to the traditional capital maintenance model. As such, it has also been a primary point of reference for both academic ${ }^{118}$ and legislative ${ }^{119}$ proposals for reform of creditor protection at the EU level. Recently, a solvency certificate has been introduced into the EU cross border conversion legislation to protect creditors against the risk of the insolvency of the company following a cross border transaction. ${ }^{120}$ The solvency-based approach has also influenced national reform movements across mainland Europe. Namely, a tendency has emerged across the EU to reduce or abolish the minimum capital and creditor protection mechanisms grounded on strict company law rules, in particular for LLCs. $^{121}$

For example, the Netherlands has completely abandoned the minimum capital requirement for private companies and replaced it with the balance sheet and solvency tests as a novel creditor protection mechanism. ${ }^{122}$ Countries like the UK have turned to a solvency based approach for capital reductions in private companies. ${ }^{123}$ Public limited companies - the core of traditional legal capital rules - have also witnessed remarkable changes. France, for example, has abandoned the minimum share capital for simplified public limited companies (société par actions simplifiée). ${ }^{124}$ However, the provisions on public limited

directors authorizing the payment shall sign a certificate that the company will remain solvent, stating their grounds ('solvency certificate'). If there were no reasonable grounds for assessing that the company will meet the solvency test (i.e. maintain both trading and balance sheet solvency) at the time of implementation of the certificate, the directors will be held personally liable for return of excessive dividends which cannot be recovered from the shareholders. Ibid., $\S 56$ (2). See more in Rickford, op. cit. (n. 5), pp. 972-975; 1025; KPMG Study, pp. 242-243; Jakšić, Petrović, op. cit. (n. 5), pp. 1105-1106.

118 KPMG Study, p. 307 (summary of academic proposals); Hopt, op. cit. (n. 3), p. 18; Rodés Saldaña, op. cit. (n. 5), p. 114; Ferran, op. cit. (n. 5), p. 538; Petrović; Jakšić, op. cit. (n. 5), p. 1115 (for ltds). For a critical appraisal of US solutions in the continental context see Jovanovič, op. cit. (n. 5), pp. 538-539.

119 AP 2003, p. 20; the SPE Proposal, Art. 21.

120 See Directive (EU) 2019/2121 of the European Parliament and of the Council of 27 November 2019 amending Directive (EU) 2017/1132 as regards cross-border conversions, mergers and divisions (Text with EEA relevance) (OJ L 321, 12/12/2019), pp. 1-44, recital 25. Critically on such approach Akšamović, D.; Šimunović, L.; Kuna, I.: Cross-Border Movement of Companies: The New Rules on Cross Border Conversion, EU and comparative law issues and challenges series (ECLIC), 3, 2019, [http://doi.org/10.25234/eclic], pp. 958-959, [available at https://hrcak.srce.hr/ojs/index.php/eclic/article/view/9038/5121], accessed 16/06/2020.

121 Company Law Study, p. 222.

122 See more on this in Ringe, op. cit. (n. 64), p. 10; Jakšić, Petrović, op. cit. (n. 5), p. 1109.

123 See more in Ferran, op. cit. (n. 5), pp. 530-535.

124 See the French Commercial Code, as last amended on June 5, 2020, Art. 227-1 in con- 
companies (sociétés anonymes) remain applicable to simplified PLCs only if those provisions are compatible with the simplified regime. ${ }^{125}$.As the idea of the simplified regime was to leave the traditional share capital rules, which rely on the balance sheet test, it is doubtful whether the current solution - under which the balance sheet test from Art. 232-11, para 3 of the Commercial Code shall also apply to simplified companies -is meaningful for dividend distribution under the simplified regime. As abandonment of the legal capital rules would suggest introducing an alternative mechanism(s) for prudent dividend distribution, the simplified regime should be replaced with a solvency test.

In March 2020 Poland also introduced a new simplified public limited company (gprosta spółka akcyjn) with only 1 Polish zloty minimum capital required for company formation. Save for certain limitations, shareholders can now get a dividend from the assets of a simple public limited company, including the legal capital. ${ }^{126}$

In light of the foregoing considerations, the following chapter will give a closer look at the Croatian capital maintenance regime, and the reform potentials thereof.

\section{SOLVENCY TEST AND CROATIAN COMPANY LAW}

\subsection{PUBLIC LIMITED COMPANIES}

\subsubsection{STATE OF THE ART}

Croatian company law follows the Germanic legal capital system. Through German solutions, Croatia has implemented EU company law rules on legal capital. ${ }^{127}$ Domestic rules on dividend distribution for public limited companies are based on the prescriptive twofold cumulative enhanced balance sheet (net asset) test and 'modified' earned surplus (accumulated running profit and

junction with Art. 224-2. Available at [https://www.legifrance.gouv.fr/affichCode.do?cidTexte $=$ LEGITEXT000005634379\&dateTexte $=20130701]$, accessed 16/06/2020. See also Ringe, op. cit. (n. 64), p. 9; Jakšić, Petrović, op. cit. (n. 5), p. 1111.

125 Arg. ex the French Commercial Code, Art. 227-1, para 3.

126 See more in Mazgaj, M.; Mucha, A.: The New Kid on the Block on the European Market for Corporate Legal Forms: A Polish Laboratory for a Modern Close Corporation, European Company Law (EUCL), 17(2), 2020, pp. 45-52, available at [https://kluwerlawonline.com/journalarticle/European+Company+Law/17.2/EUCL2020008], accessed on 06/07/2020.

127 Barbić, J.: Utjecaj njemačkog prava na stvaranje hrvatskog prava društava, Zbornik radova Pravnog fakulteta u Splitu, 44(3-4), 2007, p. 354. 
loss account) test. ${ }^{128}$ The mandatory character of the present EU rules does not leave much room for departures thereof. ${ }^{129}$ However, given the minimum harmonization standard of the EU capital maintenance regime, Croatia could introduce complementary arrangements for efficient creditor protection with regard to PLCs ('dionička društva').

Some of the civil law arrangements have already been put in place, most notably, the remedial schemes. Unless their decision to pay dividend follows the prior approval of the general meeting of shareholders, directors shall be jointly and severally liable to the company for breach of distribution rules. ${ }^{130}$ In that case, the company's creditors could claim damages on behalf of the company if the company was not able to meet their claims as they fall due. ${ }^{131}$ Notwithstanding the directors' liability, the shareholders are liable for the return of the unlawfully paid dividend if the company proves they knew or ought to know that they had not been entitled to receive it. ${ }^{132}$ In case the company is unable to pay their outstanding claims as they fall due, the creditors may claim the dividend back on behalf of the debtor company. ${ }^{133}$ Moreover, shareholders' liability may arise as a consequence of any kind of malicious undercapitalization of the company's assets which has led to the company becoming insolvent and, hence, unable to meet creditors' claims as they fall due. ${ }^{134}$

There are no obstacles for the parties to refer to the conventional contractual or property law mechanisms of creditor protection such as floating charges ${ }^{135}$ and bank loan covenants. However, it would not be possible under Croatian law for the creditors to contract for direct restrictions on dividend distributions, and thereby circumvent strict CA rules. Namely, shareholders are entitled to profit

128 The Croatian Companies' Act, (NN no. 111/93, 34/99, 121/99, 52/00, 118/03, 107/07, $146 / 08,137 / 09,125 / 11,152 / 11,111 / 12,68 / 13,110 / 15,40 / 19)$, Art. 220 para. 7 . Hereinafter referred to as the CA. Modified due to the fact that Croatia has added available reserves to the earned surplus. For the definition of the modified earned surplus test see Rickford, op. cit. (n. 5), p. 969, footnote 178 .

129 Jovanovič, op. cit. (n. 5), p. 537.

130 CA, Art. 252, para. 3, subpara. 2.

131 CA, Art. 252, para. 5.

132 CA, Art. 224,para. 1.

133 CA, Art 224, para. 2.

134 CA, Art. 10, para. 4.

135 The Act on the Register of Judicial and Public Notaries' Security Interests on Movables and Intangibles, (NN no. 121/05), Art. 38. It should be noted that Croatian floating charge departs from its Anglosaxon role-model, as it may charge only some generic movables stored in a designated storage or other premise, hence, not the whole undertaking belonging to the debtor company. 
distribution unless the general meeting decided otherwise in accordance with the limits prescribed by the law or memorandum of association (emphasis added). ${ }^{136}$ If there are no legal (including balance sheet) or internal (statutory) restraints on dividend distribution, shareholders' meeting has sole discretion to decide whether and how much dividend will be paid to the shareholders. ${ }^{137}$ Therefore, no contractual covenant could lawfully preclude shareholders from the dividend payment. Any private law covenant imposing direct limits on the debtor company (e.g. tying the distributable amount to the profit rate or a certain percentage of profit) should be hence considered as unlawfully interfering with the competencies vested in the general meeting of shareholders under the strict distribution rules. ${ }^{138}$ The shareholders' decision which would be grounded on such an unlawfully precluding covenant would be voidable, as the decision would contravene the strict distribution rules set out in CA. ${ }^{139}$ Breach of such a precluding contractual covenant could, however, result in civil law liability of the company to the creditors (inter partes).

A private law restriction could bind the company's shareholders by amending the company's memorandum of association with the same qualified majority of shareholders' votes that is required for the memorandum's amendments. In that case, direct distribution restriction would no more be an 'externally' negotiated clause depriving the shareholders of their legal right, but rather a self-imposed collective covenant or term adopted into the basic corporate act, binding the shareholders' meeting.

The majority shareholder, as any other shareholder, has the sole discretion to decide whether to vote for dividend payment, how and for what reason. However, it may be argued that a strong letter of comfort, that binds a majority shareholder (i.e. the parent company) not to vote for dividend payment so as to maintain the payer company's liquidity, and thus increase the bank's payment prospects, would be precluded for the competences of the shareholders' meeting. Unless the objective (economic) circumstances surrounding the debtor company suggested abstaining from dividend payment, ${ }^{140}$ a letter of this sort would directly affect a majority shareholder's decision on dividend payment to the detriment of minority shareholders on grounds other than legal, statutory, or economic. It follows that a decision not to distribute dividend does not rely solely on the majority shareholder's sole discretion (whatever the reasons for

136 CA, Art. 220,para. 6.

137 Barbić,op.cit. (n. 24), p. 1341.

138 Likewise for Germany see KPMG Study, p. 74.

139 Arg ex CA, arts. 360 para. 1 and 365 para. 1.

140 Arg ex CA, Art. 365 para. 1. 
such a decision might be), restraints prescribed by the law (including restraints imposed by the mandatory twofold balance sheet test), and the company's memorandum of association. A decision not to pay dividends must employ an additional line of reasoning which, for the purposes of this paper, may be referred to as the 'circumstances test'. Otherwise, a decision to withhold dividend may be challenged at court as voidable if such a decision deprived (minority) shareholders from receiving dividend notwithstanding, on the one part, that no legal or company's internal act precluded such payment and, on the other part, a judgment of a reasonable business person would suggest a positive decision having regard the 'circumstances' surrounding the company. Shareholders could file a civil lawsuit asking the court to declare the withholding decision null and void and to bind the company to pay the disputed amount to the shareholders. However, if the shareholders asked the court to declare the only nullity of the withholding decision, but not the payment of dividend, the judgment would not be a valid ground for the payment per se. Instead, the company should convene a new general meeting of shareholders and render a new decision to distribute dividends, given that the previous one was declared null and void. ${ }^{141}$

Therefore, under the Croatian distribution rules, a prudent distribution process in public limited companies should apply both a twofold positive balance sheet test and a complementary ex ante 'circumstances' test to avoid court proceedings declaring the withholding decision null and void. ${ }^{142}$ The CA, however, does not precise what kind of circumstances should influence the shareholders' decision to pay dividends. It may be argued that such an 'aptitude test' should assess - in the first place - the current economic and financial circumstances surrounding the company. Such assessment may include factors such as the company's overall financial position (financial risk management, including price-fluctuation risks, credit risks, cash-flow risks, currency risks, contingent, and prospective liabilities, supply and demand ratio, etc.); foreseeable development of the company; planned investments, research, and development (R\&D) activities; state of the company's reserves; expected capital alteration activities, share-buy backs programs, security interests over third-parties' property (financial instruments, charges), company's place in the market competition, etc. ${ }^{143}$ An ample wording of the 'circumstances' test from Art. 365, para $1 \mathrm{CA}$ allows directors to consider a lot of factors indicating the company's short-term (liquidity) and long-term (solvency) payment prospects, and, therefore, in a way already (though, tacitly) incorporates a 'com-

${ }_{141}$ Barbić, op. cit. (n. 24), p. 1390.

${ }^{142}$ Arg.ex CA, Art. 220 para. 7 in conjunction with Art. 365 para. 1.

143 Arg. ex CA, Art. 250 (a) para. 3. 
mercial', solvency-based standards into Croatian distribution rules. However, the Croatian distribution rule refers to the overall circumstances surrounding the company, and not mere economic/financial indicators. The 'circumstances test' should additionally review current non-financial (social) indicators surrounding the company's business such as environmental, labor, public health and human rights concerns, anti-corruption and bribery policy, diversity on board, geopolitical risks, pending legal reforms, and alike. ${ }^{144}$

\subsubsection{PROSPECTS}

\subsubsection{Basic Form of Public Limited Company}

Despite of the argument that the solvency-based standards are implicitly provided under the current CA rules, and should be employed as part of the overall 'circumstances test', future reforms of Croatian company law should consider introducing an explicit provision on trading solvency into the CA distribution regime to complement the mandatory balance sheet test and financial accounts. Corporate directors would be asked to monitor and assess the solvency prospects of the company before submitting the distribution proposal to the shareholders' meeting. It would force them to consider trading solvency standards such as market capitalization, expected liabilities, cash flow, etc. when rendering a distribution decision, and not mere balance sheet figures and financial reports. However, a reference to the balance sheet test should precede the trading solvency assessment. If the balance sheet test demonstrates (threatening) insolvency, the trading solvency test should not be undertaken, especially not with the aim to override the results under the balance sheet test. 145 The distribution should follow only if both the balance sheet test and trading solvency test were met.

The proposed regime would certainly benefit the creditors, as it would prevent excessive dividend distribution under the positive balance sheet regime unless the trading solvency test confirmed positive results. The incorporation of the solvency- based test into the distribution rules would bring current, future, adjusting, and non-adjusting creditors on a level playing field, as an ex ante general distribution rule would allow both actual (on-balance sheet) and expected (prospective or contingent, off-balance-sheet) liabilities to be considered, making the distribution neutral and less static.

\footnotetext{
144 Arg. ex CA, Art 250 (a) para. 2. See Barbić, op. cit. (n. 24), p. 1342.

145 In favor of the more relaxed approach, where the results of the solvency test should override the outcomes of the balance sheet test in case the latter demonstrates the balance sheet insolvency Rickford, op. cit. (n. 5), p. 995; see also KPMG Study, p. 307.
} 
Furthermore, a distribution scheme relying on trading solvency standards would certainly bring long-term financial benefits for the shareholders. It would encourage directors of listed companies to carefully consider how a commercial approach might contribute to the company's long-term business strategy and its sustainability. The company's remuneration policy should reflect the outcomes of their assessment, rewarding those who employed a sound distribution policy while meeting the shareholder's expectations. ${ }^{146}$ From that point of view, tying the shareholders returns to the assessments of the company's actual trading solvency should increase the company's financial sustainability over some longer period of time, reduce directors' opportunistic behavior, encourage them to take a forward-looking approach, and make the shareholders' stakes more valuable and attractive in the long run.

Given the Anglo-American legal origin of the standard solvency test, particular attention should be paid to making it compatible with the existing rules on distribution in order to avoid possible inconsistencies within the system. ${ }^{147}$ Therefore, de lege ferenda solvency test should not be accompanied by the solvency statement, as direct transposition of the Anglo-American solutions would interfere with the traditional division of competences in public companies. ${ }^{148}$ Namely, under Anglo-American corporate governance, the board of directors has sole discretion to declare distributable profits. ${ }^{149}$ It shall be solely liable for any misstatements affecting the lawfulness of the distribution, along with the liability for return of the unlawfully paid dividend. Hence, it makes sense to ask the board to state, certify, and publish the company's foreseeable solvency before the distribution takes place. ${ }^{150}$ However, under the continental jurisdictions, the division of competences among corporate bodies is less 'board-centered'. The shareholder's meeting is solely competent to render a final decision on dividend distribution. ${ }^{151}$ The sole liability for the return of the unlawfully paid dividend remains with the shareholders. ${ }^{152}$ In such a "shareholder-centered' distribution scheme it would be hard to introduce a legislative solution that would make the directors liable for payments that were made without their direct involvement. ${ }^{153}$ What, however, does make sense is to ask

146 CA, Art. 247 (a) and 272 (r) para. 1, subpara.1.

147 Barbić, op.cit. (n. 127) p. 347.

148 The same Jovanovič, op. cit. (n. 5), p. 539.

149 KPMG Study, p. 30 (UK); ibid., pp. 157-159 (US); ibid., p. 168 (Delaware); ibid., p. 190

(California); ibid., p. 206 (Canada); ibid., p. 224 (Australia); ibid., p. 243 (New Zealand).

150 The same Jovanovič, op. cit. (n. 5), p. 539.

151 The same ibid. See CA, Art. 275 para. 1 subpara. 2.

152 CA, Art. 224,para. 1.

153 The same Jovanovič, op. cit. (n. 5), p. 539. 
the directors to assess the company's foreseeable solvency (e.g. by referring to the company's solvency prospects in the special section of the annual management report) ${ }^{154}$ before covering the shareholders' meeting.

The solvency test could thus serve as a point of reference for the shareholders once the directors' distribution proposal is placed on the meeting's agenda. Nonetheless, it would not preclude the meeting's ultimate responsibility for the payment. Shareholders are not tied to the directors' proposal. They can reject it, revise the decision already rendered, ${ }^{155}$ or even remove the proposal from the meeting's agenda if they disagree with it. ${ }^{156}$ In any case, they should double-check the financial and management reports. ${ }^{157}$ Unless their order to transfer dividends was not based on the shareholders' approval, the directors would not be liable for damages to the company resulting from a shareholders' decision to distribute profit. ${ }^{158}$ Furthermore, it should be noted that creditors' claims are merely accessory to the company's claim against the directors. ${ }^{159}$ As there would be no liability claim against the directors, the creditors would not succeed with their civil lawsuit against the board members either, notwithstanding the fact that the company might have become insolvent as a result of the unlawful distribution. ${ }^{160}$

\subsubsection{Novel Form}

Under the existing EU capital maintenance regime, the solvency test may serve only as a complementary yardstick for dividend distribution in basic public limited companies, i.e. those listed in the Annex to the Codification. However, there are no limitations on introducing such a test as a sole mechanism for creditor protection in other (non-listed) corporate forms of public limited companies. As stated earlier, some EU Member States have recognized such a harmonization gap and decided to introduce a simple public limited company having no or modest share capital. ${ }^{161}$

\footnotetext{
154 See CA, Art. 250 (a) paras. 2 and 3 (b).

155 Barbić, op. cit. (n. 24), p. 1179.

156 Ibid., p. 1181.

157 CA, Art. 276 para. 3. The shareholders' meeting may even revisit the financial report. CA, Art. 300 (e) para. 3.

158 CA, Art. 252 para. 4. This, however, does not preclude directors' liability for unlawful dividend distribution if the shareholders decision was grounded on inaccurate, incomplete and incorrect financial statements and reports.

159 Arg ex CA, Art. 252 para. 5. Barbić, op. cit. (n. 24), p. 815.

160 Contrary ibid., p. 822.

161 See supra section 2.3.3.
} 
Croatia could follow suit and introduce a simple plc ('jednostavno dioničko društvo') having no or only 1 HRK minimum share capital. As such a move would downplay the 'guarantee' role of the share capital, there would be a need for introducing a novel, solvency-based test as the only mechanism of creditor protection. Under such a distribution regime, the company's directors would not be bound to check the balance-sheet solvency but rather the trading solvency. Alternatively, the balance sheet could still serve as a starting reference point in the due process of dividend distribution but could be, for example, overridden in favor of the solvency assessment as the final yardstick for deciding on the distributable profit. However, interfering with the minimum capital requirement does not mean that the entire concept of share capital should be abolished. As share capital serves means other than a mere profit distribution (e.g. as a yardstick for determination of shareholders' voting rights), it should be kept while leaving to the shareholders to determine its amount on company formation ${ }^{162}$ and capital increase, respectively.

\subsection{PRIVATE LIMITED COMPANIES}

\subsubsection{STATE OF THE ART}

As EU company law does not harmonize issues related to private limited companies, ${ }^{163}$ EU Member States have sole discretion to choose the applicable distribution regime for private limited companies. ${ }^{164}$ Unlike Germany, Croatia decided not to broaden the substantive scope of the Second Company Law Directive to private limited companies. Instead, the dividend distribution rules in private limited companies refer solely to the simple earned surplus (net profit) test. ${ }^{165}$ Such a test, however, must mutatis mutandis consider the 'circumstances' test, as otherwise, the shareholders' decision to withhold distribution of dividend could be void. ${ }^{166}$ It follows that under Croatian company law a dividend in private companies may be lawfully and validly paid following the application of the cumulative 'earned surplus' and 'circumstances' test unless the shareholders' meeting has decided otherwise on the grounds of law or articles of associations. ${ }^{167}$

162 Jakšić; Petrović, op. cit. (n. 5), p. 1115.

163 Jovanovič, op. cit. (n. 5), p. 537.

164 Ibid., p. 542.

165 CA, Art. 406, para. 1. In favour of such interpretation of EU solutions on private companies also Rickford, op. cit. (n. 5), p. 991.

166 Arg. ex CA, Art. 449 in conjunction with Art. 365 para. 1 CA.

167 CA, Art. 406 in conjunction with arts. 449 and 365 para. 1 CA. 


\subsubsection{PROSPECTS}

De lege ferenda Croatia could use the EU harmonization gap so as to introduce a novel private limited company lacking any minimum capital requirement, and a solvency-based test for the purpose of the determination of the distributable amount. ${ }^{168}$ Such a test could supplement the current operating net profit test, or replace it completely, as no 'top-down' EU rules exist in this field of law. Along the same lines of reasoning as with regard to the public limited companies, share capital should be kept while leaving to the shareholders to determine its amount on company formation ${ }^{169}$ and capital increase, respectively.

\section{CONCLUSION}

For over a century the continental legal doctrine has considered share capital as an important guarantee for securing creditors' rights, and a barrier to shareholders' and directors' reckless behavior. However, the perspective has changed at the outset of the twenty-first century, mostly as a result of the influx of the Anglo-American liberal doctrine. From that moment on the traditional rules on the share, capital maintenance has been criticized for providing an inaccurate picture of the company's net asset structure. As share capital lacks any guarantee function, insisting on minimum capital contributions on the company's formation has been regarded as a disproportionate and deterring incorporation requirement. Furthermore, the share capital concept relies on the numbers ('balance sheet solvency') rather than on the company's actual commercial position ('trading solvency'), allowing the critics to object that the concept is too mechanic and, hence, detached from the company's economic context.

Many have urged for revisiting the EU legal capital regime, which follows the traditional legal capital doctrine. On the one hand, there have been suggestions that the existing system should be completely abandoned in favor of the solvency test. On the other hand, most authors urge for less radical solutions, viz. leaving the legal capital concept while complementing it with contractual, property, and company law tools. At a practical level, contractual and property mechanisms such as bank covenants, guarantees, pledges, and floating charges are often contracted for by major, voluntary creditors, and serve to protect their claims ex ante. At the company law level, hard law mechanisms such as man-

168 Jakšić; Petrović, op. cit. (n. 5), p. 1115.

169

Ibid. 
datory transparency and disclosure rules are usually complemented by voluntary soft law measures such as recommendations and corporate governance codes. Along with their preventive role, company law tools may also serve as ex post remedies seeking the return of the unlawfully disposed company equity from the shareholders, compensation for damages from the corporate directors, or asking the opportunistic shareholders to take liability for creditors' claims in case of company's insolvency. Those remedies are particularly apt for the protection of non-voluntary creditors, who had been deprived of the possibility to contract for legal protection.

However, private law mechanisms demonstrate certain weaknesses. They are either reserved for major creditors, voluntary in their application, or difficult to enforce. Therefore, in pursuit of an efficient mean of creditor protection, one has to turn to a commercially oriented distribution yardstick that can force directors to assess ex ante the potential outcomes of the distribution in light of the actual economic surroundings of the company, be more inclusive, and render the directors liable where there was no reasonable economic case for dividend distribution. Such an approach requires introducing solvency-based standards into the existing EU distribution regime. Unfortunately, not much has been done so far at the EU level to revise the current mandatory legal capital regime either in terms of replacing it or complementing it with a solvency test. Early attempts to introduce a novel EU private company form, having a symbolic amount of legal capital and the solvency test as a yardstick for dividend distribution, have failed due to conceptual dissents at the highest EU institutional levels.

Nonetheless, the normative restraints coming from the mandatory character of the EU capital maintenance regime are not as precluding as it might seem at first glance. The Codification provides only minimum safeguards for creditor protection and does so only for a numerus clausus of public limited companies. Such a scope of the substantive application allows, on the one hand, the coexistence of the prescriptive capital safeguards and civil law arrangements in basic public limited companies. Those civil arrangements act, hence, as complementary tools for potentially endangered creditors' claims in case of otherwise lawful capital returns. On the other hand, such a scope of application does not preclude the EU Member States to introduce the novel, alternative corporate forms of public companies ('simple PLCs'). Novel corporate forms, being outside the harmonized area of EU company law, would not be subject to traditional legal capital rules. Such corporate forms may relate their distribution regimes to any economically sound scheme, including but not limited to solvency tests. Likewise, EU Member States have sole discretion to introduce their own distribution schemes for private limited companies, as this area of company law falls within the ambits of national company laws. 
Cases of France, the Netherlands, and Poland demonstrate the willingness of continental jurisdictions to dilute the traditional legal capital concept, including the distribution restraints arising from the balance sheet test. Along these lines, Croatian legislator could introduce trading solvency test into the CA as an additional, third-level yardstick for prudent dividend distribution in the traditional public limited company ('d.d.') and an exclusive or additional yardstick for dividend distribution in some novel corporate form (e.g. 'simple d.d.'). Asking the corporate directors to take regard of the company's solvency prospects would be for the benefit of voluntary and involuntary creditors, as both categories would be equally secured against rash decisions on dividend distribution. Furthermore, tying the company's remuneration policy to the longterm outcomes of the prudent dividend distribution policy would significantly stimulate directors' forward-looking approach, and, hence, contribute to the idea of the sustainable company ('going-concern' approach).

Speaking of its design, the solvency test should regard various socio-economic circumstances indicating the company's solvency prospects, where balance sheet solvency and earned surplus would/could serve only as a starting point of reference. The final decision on the distribution would depend on the overall economic and social assessment of the company's position instead of bare financial numbers. Such a test should, however, not be accompanied by the solvency statement, as such a solution would interfere with the existing Croatian regime of the division of competences within a company. Mutatis mutandis, solvency test could be applied to other forms of distributions that have so far relied on the two-fold balance sheet test. Given that the private limited company regime has already turned to the net profit test, there are no obstacles for turning to the solvency assessment as a complementary or exclusive means of dividend distribution in (simple) private limited companies. However, introducing a solvency test should not make the legal capital doctrine complete obsolete. As legal capital rules serve purposes other than mere capital distribution, they should be kept at some minimum level, and aligned with the modernized distribution rules.

\section{LITERATURE}

1. Akšamović, D.; Šimunović, L.; Kuna, I.: Cross-Border Movement of Companies: The New Rules on Cross Border Conversion, EU and comparative law issues and challenges series (ECLIC), 3, 2019, [http://doi.org/10.25234/eclic], pp. 943-966, [available at https:/hrcak.srce.hr/ojs/index.php/eclic/article/view/9038/5121], accessed 16/06/2020

2. Armour,J.: LegalCapital: An Outdated Concept? European Business Organization Law Review (EBOR), 7(1) 2006, [https://doi.org/10.1017/s156675290600005x],pp. 
1-18, available at [https://papers.ssrn.com/sol3/papers.cfm?abstract_id=910826], accessed 04/06/2020

-DOI: https://doi.org/10.1017/S156675290600005X

3. Barbić, J. et al.: Korporativno upravljanje: osnove dobre prakse vođenja društva kapitala, Zagreb, 2008

4. Barbić, J.: Pravo društava. Knjiga Druga. Društva kapitala. Svezak I.: Dioničko društvo, Peto, izmijenjeno i dopunjeno izdanje, Organizator, Zagreb, 2010

5. Barbić, J.: Utjecaj njemačkog prava na stvaranje hrvatskog prava društava, Zbornik radova Pravnog fakulteta u Splitu, 44(3-4), 2007, pp. 339-363

6. Bratton, W. W.; McCahery, J. A.; Vermeulen, E. P. M.: How Does Corporate Mobility Affect Lawmaking? ECGI - Law Working Paper No. 91/2008; Georgetown Law and Economics Research Paper No. 1086667; Amsterdam Center for Law \& Economics Working Paper No. 2008-01, 2008, [https://doi.org/10.2139/ ssrn.1086667], pp. 1-44, available at [https://ssrn.com/abstract=1086667], accessed 09/06/2020

7. Čulinović-Herc, E.: Zalaganje imovine trgovačkih društava: engleski Floating Charge i Enterprise Charge model-zakona o osiguranju potraživanja Europske banke, Zbornik Pravnog fakulteta u Zagrebu, 45(1), 1995, pp. 93-120

8. Ferran, E.: Revisiting Legal Capital, European Business Organization Law Review (EBOR), 20(3) 2019, [https://doi.org/10.1007/s40804-019-00161-z], pp. 521545, available at [https://papers.ssrn.com/sol3/papers.cfm?abstract_id=3449052], accessed 04/06/2020

-DOI: https://doi.org/10.1007/s40804-019-00161-z

9. Gavella, N. (ed), Stvarno pravo, Svezak 1., Narodne novine, 2007

10. Gerner-Beuerle C. et al:: Study on the Law Applicable to Companies Final Report, Directorate-General for Justice and Consumers (European Commission) and the London School of Economics and Political Sciences, June 2016, available at [https://op.europa.eu/en/publication-detail/-/publication/259a1dae-1a8c-11e7-808e-01aa75ed71a1], accessed on 04/06/2020

11. Gerner-Beuerle, C.; Paech, P.; Schuster, E. P.: Study on Directors Duties and Liability, London School of Economics and Political Scienes, London, April 2013, available at [http://eprints.lse.ac.uk/50438/1/__Libfile_repository_Content_Gerner Beuerle,\%20C_Study\%20on\%20directors\%E2\%80\%99\%20duties\%20 and\%20liability(lsero).pdf], accessed 06/07/2020

12. Hopt, K.: Comparative Company Law 2018, ECGI Working Paper No. 460/2019, July 2019, [https://dx.doi.org/10.2139/ssrn.3421389], pp. 1-39, available at [https:// papers.ssrn.com/sol3/papers.cfm?abstract_id=3421389], accessed on 04/06/2020

13. Horak H.; Bodiroga Vukobrat, N.: Comply or Explain Experiences of the EU Member States, in: Horak et al., Hrvatsko i europsko pravo društava/Croatian \& European Company Law, Zbornik radova/Collection of Proceedings, pp. 36- 
55, available at [http://www.efzg.unizg.hr/userdocsimages/PRA/2017\%20-\%20 novi\%20web/Publikacije/hrvatsko_i_europsko_pravo_drutava_2.pdf], accessed on $04 / 06 / 2020$

14. Horak, H.; Dumančić K.: Introduction of the Business Judgement Rule into Croatian Legislation, in: Horak et al., Hrvatsko i europsko pravo društava/Croatian \& European Company Law, Zbornik radova/Collection of Proceedings, pp. 120133, available at [http://www.efzg.unizg.hr/userdocsimages/PRA/2017\%20-\%20 novi\%20web/Publikacije/hrvatsko_i_europsko_pravo_drutava_2.pdf], accessed on $04 / 06 / 2020$

15. Horak, H.; Dumančić, K.; Poljanec, K.: Modernizacija i usklađivanje prava društava u Republici Hrvatskoj sa pravnom stečevinom Europske unije i načelo transparentnosti podataka, in Zbornik radova: II. Međunarodna konferencija Bosna i Hercegovina i euroatlantske integracije. Trenutni izazovi i perspektive, 2014, pp. 575-600

16. Horak, H.; Dumančić, K.; Šafranko, Z.: Komparativni osvrt na jednostavno društvo s ograničenom odgovornošću, Pravo i porezi, 22 (4), 2013, pp. 37-43

17. Horak, H.; Dumančić, K.; Šafranko, Z.: Sloboda poslovnog nastana trgovačkih društava u pravu Europske unije, Ekonomski fakultet Zagreb, 2013, available at [http://www.efzg.unizg.hr/userdocsimages/PRA/2017\%20-\%20novi\%20 web/Publikacije/SLOBODA\%20POSLOVNOG\%20NASTANA.pdf], accessed $09 / 06 / 2020$

18. Horak, H. et al., European Market Law: Handbook, Vol. 1, Voronezh/ Zagreb, 2014

19. Horak, H.; Poljanec, K.: Fighting Short-Termism in EU Company Law after the Financial Crisis, European Company Law (EUCL), 17(4), 2020, pp. 115-122, available at [https://kluwerlawonline.com/journalarticle/European+Company+Law/17.4/EUCL2020018], accessed on 03/08/2020

20. Jakšić, T.: Čvrste pokroviteljske izjave - pravna narav ugovora, predmet i povreda obveze pokrovitelja, stečajni postupak i postupak izvanredne uprave, Zbornik Pravnog fakulteta Sveučilišta u Rijeci, 39(2), 2018, [https://doi.org/10.30925/ zpfsr.39.2.3], pp. 773-807

-DOI: https://doi.org/10.30925/zpfsr.39.2.3

21. Jakšić, T.; Petrović, S.: Mogući pravci izmjena i dopuna hrvatskog prava društava, Zbornik Pravnog fakulteta Sveučilišta u Rijeci, 37(3) 2016, pp. 1101-1148

-DOI: https://doi.org/10.30925/zpfsr.37.3.3

22. Jovanovič, D.: Svrha temeljnog kapitala u pravima EU, Pravo u gospodarstvu: časopis za gospodarsko-pravnu teoriju i praksu, 48(2) 2009, pp. 507-543

23. Klein, I.: A Change in Accounting, A Change in Law, Delaware Journal of Corporate Law (DJCL), 42(1) 2017, pp., 1-24, available at [https://papers.ssrn.com/sol3/ papers.cfm?abstract_id=2840968], accessed on 04/06/2020 
24. Markovinović, H.; Bilić, A.: The transfer of a company seat to a different member state in the light of the recent 'Polbud' decision, InterEULawEast: Journal for International and European Law, Economics and Market Integrations, 5(2), 2018, [https://doi.org/10.22598/iele.2018.5.2.3], pp. 97-122

-DOI: https://doi.org/10.22598/iele.2018.5.2.3

25. Maurović, Lj.: Directive 2006/68/EC Amending the Second Company Law Directive EU as Regards the Maintenance of Public Limited Liability Companies' Capital and the Acquisition of Own Shares, 2013, [https://dx.doi.org/10.2139/ ssrn.2237882], pp. 1-13, available at [https://papers.ssrn.com/sol3/papers.cfm?abstract_id=2237882], accessed on 04/06/2020

-DOI: https://doi.org/10.2139/ssrn.2237882

26. Mazgaj, M.; Mucha, A.: The New Kid on the Block on the European Market for Corporate Legal Forms: A Polish Laboratory for a Modern Close Corporation, European Company Law (EUCL), 17(2), 2020, pp. 45-52, available at [https://kluwerlawonline.com/journalarticle/European+Company+Law/17.2/ EUCL2020008], accessed on 06/07/2020.

27. Rickford, J.(ed): Reforming Capital, Report of the Interdisciplinary Group on Capital Maintenance, European Business Law Review (EBLR), 15(4) 2004, pp. 920-1027, available at [https://www.biicl.org/files/916_capital_maintenance_report_-_final.pdf], accessed on 04/06/2020

28. Ringe, W. G.: Corporate Mobility in the European Union - A Flash in the Pan? An Empirical Study on the Success of Lawmaking and Regulatory Competition, Ringe, Oxford Legal Studies Research Paper No. 34/2013; European Company and Financial Law Review 2013; Oxford Legal Studies Research Paper No. 34/2013; University of Oslo Faculty of Law Research Paper No. 2013-19, 2013, [https://doi.org/10.2139/ssrn.2291860], pp. 1-41, available at [https://ssrn.com/abstract $=2247323]$, accessed 09/06/2020

29. Rodés Saldaña, L.: Suitability of EU Legal Capital Rules as a Mechanism of Creditor Protection: A Comparative and Functional Study, Doctoral Thesis, University of Leicester Law School, Leicester, 2019

30. Siems, M.; Herzog,L.; Rosenhäger, E.: The European Private Company (SPE): An Attractive New Legal Form of Doing Business?, Butterworths Journal of International Banking and Financial Law, February 2009, pp. 1-12, available at [https:// papers.ssrn.com/sol3/papers.cfm?abstract_id=1350465], accessed 04/06/2020

31. Strampelli G.: The IAS/IFRS After the Crisis: Limiting the Impact of Fair Value Accounting on Companies' Capital, European Company and Financial Law Review, De Gruyter, 8(1) 2011, [https://doi.org/10.1515/ecfr.2011.1], pp. 1-29, available at [https://ideas.repec.org/a/bpj/eucflr/v8y2011ilp1-29n1.html], accessed on 04/06/2020

-DOI: https://doi.org/10.1515/ecfr.2011.1

32. Tipurić, D.: Nadzorni odbor i korporativno upravljanje, Zagreb, 2006 


\section{LEGISLATION}

1. Canada Business Corporations Act, R.S.C., 1985, c. C-44 (last amended January 1, 2020), available at [https://laws-lois.justice.gc.ca/PDF/C-44.pdf], accessed $16 / 06 / 2020$

2. Directive (EU) 2019/2121 of the European Parliament and of the Council of 27 November 2019 amending Directive (EU) 2017/1132 as regards cross-border conversions, mergers and divisions (Text with EEA relevance) (OJ L 321, 12/12/2019), pp. $1-44$

3. Directive 2013/34/EU of the European Parliament and of the Council of 26 June 2013 on the annual financial statements, consolidated financial statements and related reports of certain types of undertakings, amending Directive 2006/43/EC of the European Parliament and of the Council and repealing Council Directives 78/660/EEC and 83/349/EEC Text with EEA relevance, (OJ L 182, 29/06/2013), pp. 19-76

4. Directive (EU) 2017/1132 of the European Parliament and of the Council of 14 June 2017 relating to certain aspects of company law (codification)(Text with EEA relevance), (OJ L 169, 30/6/2017), pp. 46-127

5. French Commercial Code, as last amended on June 5, 2020, available at [https:/ www.legifrance.gouv.fr/affichCode.do?cidTexte=LEGITEXT000005634379\&dateTexte $=20130701]$, accessed 16/06/2020

6. Model Business Corporation Act (2016 Revision), December 9, 2016, available at [https://www.americanbar.org/content/dam/aba/administrative/business_law/ corplaws/2016_mbca.authcheckdam.pdf], accessed 13/06/2020

7. Model Law on Secured Transactions, available at [https://www.ebrd.com/whatwe-do/legal-reform/access-to-finance/transactions.html], accessed 15/06/2020

8. Regulation (EC) No 1606/2002 of the European Parliament and of the Council of 19 July 2002 on the application of international accounting standards, (OJ L 243, 11/9/2002), pp. 1-4

9. Second Council Directive 77/91/EEC of 13 December 1976 on coordination of safeguards which, for the protection of the interests of members and others, are required by Member States of companies within the meaning of the second paragraph of Article 58 of the Treaty, in respect of the formation of public limited liability companies and the maintenance and alteration of their capital, with a view to making such safeguards equivalent, (OJ L 26, 31/1/1977), pp. 1-13

10. The Act on the Register of Judicial and Public Notaries' Security Interests on Movables and Intangibles, Official Gazzette of the Republic of Croatia, (NN no. 121/05)

11. The Companies Act 1993, No. 105, September 28, 1993, available at [http://www.legislation.govt.nz/act/public/1993/0105/latest/DLM319998.html], accessed 16/06/2020

12. The Corporations Act 2001, No. 50, 2001, Compilation No. 81, Vol. 1, September 28, 2017, available at [https://www.legislation.gov.au/Details/C2017C00328/ Download], accessed 16/06/2020 
13. The Croatian Companies' Act, (NN no. 111/93, 34/99, 121/99, 52/00, 118/03, $107 / 07,146 / 08,137 / 09,125 / 11,152 / 11,111 / 12,68 / 13,110 / 15,40 / 19)$

\section{CASE LAW OF THE CJEU}

1. Judgment of the Court (Second Chamber), Alfred Hirmann v Immofinanz AG, C-174/12, EU:C:2013:856

2. Judgment of the Court of 9 March 1999, Centros Ltd v Erhvervs- og Selskabsstyrelsen, C-212/97, EU:C:1999:126

3. Judgment of the Court of 30 September 2003, Kamer van Koophandel en Fabrieken voor Amsterdam v Inspire Art Ltd, C-167/01, EU:C:2003:512

4. Judgment of the Court (Grand Chamber) of 25 October 2017, Proceedings brought by Polbud - Wykonawstwo sp. z o.o., C-106/16, EU:C:2017:804

5. Judgment of the Court of 5 November 2002, Überseering BV v Nordic Construction Company Baumanagement GmbH (NCC), C-208/00, EU:C:2002:632

\section{DOCUMENTS OF THE EU INSTITUTIONS}

1. A Modern Regulatory Framework for Company Law in Europe: A Consultative Document of the High Level Group of Company Law Experts ('Winter Report'), available at [https://www.eerstekamer.nl/eu/documenteu/a_modern_regulatory_ framework_for/f=/vgklizzpd9we.pdf], accessed 04/06/2020

2. Communication from the Commission to the Council and the European Parliament - Modernising Company Law and Enhancing Corporate Governance in the European Union - A Plan to Move Forward, Brussels, 21.5.2003, COM/2003/0284 final/, available at [https:/op.europa.eu/en/publication-detail/-/ publication/11f14007-f2d6-4610-9bc4-2402324472f4/language-en]

3. KPMG Feasibility Study on an Alternative to the Capital Maintenance Regime Established by the Second Company Law Directive77/91/EEC of 13 December 1976 and an Examination of the Impact on Profit Distribution of the new EU-accounting Regime: Main Report, available at [https://lse.rl.talis.com/items/0FE92D26066F-2FD8-C723-2B5F1B5F28D1.html], accessed on 04/06/2020

4. Proposal for a Council Regulation on the statute for a European private company $\{$ SEC(2008) 2098\} \{SEC(2008) 2099\}/COM/2008/0396 final - CNS 2008/0130/, available at [https://eur-lex.europa.eu/legal-content/EN/TXT/?qid=1591291995560\&uri=CELEX:52008PC0396], accessed on 04/06/2020

\section{OTHER URL SOURCES}

1. [https://www.worker-participation.eu/Company-Law-and-CG/Company-Law/European-Private-Company-SPE], accessed on 02/06/2020 